\title{
Étude préliminaire du discours de présentation de la notion de marché dans les manuels d'introduction aux principes de l'économie
}

\section{Catherine Resche}

\section{(2) OpenEdition}

Journals

Édition électronique

URL : http://journals.openedition.org/asp/708

DOI : $10.4000 / a s p .708$

ISBN : 978-2-8218-0402-9

ISSN : 2108-6354

\section{Éditeur}

Groupe d'étude et de recherche en anglais de spécialité

\section{Édition imprimée}

Date de publication : 1 décembre 2006

Pagination : 93-118

ISSN : 1246-8185

Référence électronique

Catherine Resche, «Étude préliminaire du discours de présentation de la notion de marché dans les manuels d'introduction aux principes de l'économie », ASp [En ligne], 49-50 | 2006, mis en ligne le 09 février 2010, consulté le 22 mars 2021. URL : http://journals.openedition.org/asp/708 ; DOI : https:// doi.org/10.4000/asp.708

Ce document a été généré automatiquement le 22 mars 2021.

Tous droits réservés 


\title{
Étude préliminaire du discours de présentation de la notion de marché dans les manuels d'introduction aux principes de l'économie
}

\author{
Catherine Resche
}

\section{Introduction}

Cette étude a pour objet d'analyser la nature et la fonction du discours définitoire dans les manuels d'introduction à l'économie. La notion de discours définitoire au sens large du terme, sera précisée ultérieurement, mais le choix des manuels d'économie nécessite une explication immédiate. Leur intérêt est double à nos yeux : d'une part, ils représentent un aspect de la langue d'un domaine de spécialité qui est au centre de nos préoccupations, aussi bien pour notre enseignement que pour notre recherche et, d'autre part, ils constituent un genre particulier, à mi-chemin entre le discours spécialisé et académique des articles de recherche et le discours économique de vulgarisation que l'on peut trouver dans des magazines économiques. Le lectorat potentiel de ces manuels est très large, puisque les manuels anglo-saxons sont utilisés par un très grand nombre d'universités, non seulement dans les pays anglophones, mais également à l'étranger, une fois traduits. Il est utile de préciser que les universités américaines offrent la possibilité aux étudiants de toutes les disciplines, aussi bien littéraires que scientifiques, de choisir à titre d'option un enseignement d'initiation à l'économie. Les auteurs de ces manuels s'adressent tout particulièrement aux étudiants, mais ils écrivent également en pensant à leurs collègues, car, pour assurer le succès de leurs livres, et renforcer leur propre autorité, ils doivent s'efforcer de persuader le plus grand nombre d'universitaires de recommander l'adoption de ces manuels par leurs institutions. Pour ce faire, la vue d'ensemble des notions qu'ils proposent doit recueillir un large consensus. 
2 Les auteurs des manuels d'introduction aux grands principes de l'économie sont conscients de la responsabilité qui leur incombe d'initier des générations d'étudiants à une certaine vision de l'économie et à une façon de concevoir le monde qui les entoure. Dans la préface à la troisième édition de son manuel Principles of Economics, Mankiw (2004 : v) est très clair à ce sujet :

Economists have a unique way of viewing the world [...]. My goal in this book is to transmit this way of thinking to the widest possible audience and to convince readers that it illuminates much about the world around them. [...] One purpose of general education is to make people more informed about the world to make them better citizens. [...] Writing an economics textbook is, therefore, a great honor and a great responsibility. It is one way that economists can help promote better government and a more prosperous future.

On ne manquera pas de noter les idées importantes dans cette citation, portées par les formes verbales : transmettre, convaincre, informer et former de meilleurs citoyens. Indéniablement, le fait de placer à proximité les verbes « convaincre » et «informer " souligne que le recours à la rhétorique est bien envisagé dans ce discours de présentation des notions : il convient donc de garder à l'esprit l'impact qu'il peut avoir.

4 Une autre citation d'un auteur quasi mythique, Samuelson, qui a formé des générations d'étudiants depuis la première édition de son manuel en 1948, traduit la responsabilité évoquée plus haut en termes de pouvoir. Samuelson, cité par Nasar (1995), a reconnu l'impact considérable qu'il exerçait au travers de ses manuels, même si sa déclaration prend la forme d'une boutade : «I don't care who writes a nation's laws - or crafts its advanced treaties - if I can write its economic textbooks ».

Dans la mesure où une étude préliminaire doit forcément aborder un sujet plus large par un angle donné, le choix s'est porté sur le discours de présentation de la notion de marché, notion centrale en économie, principalement en microéconomie, mais qui touche également la macroéconomie. Effectivement, selon les manuels, le commerce international est abordé soit dans l'une, soit dans l'autre partie, et il est évident que les choix des agents économiques, acteurs du marché étudiés en microéconomie, dépendent également du niveau de chômage, de la politique économique menée par les autorités monétaires pour juguler l'inflation, relancer la croissance, etc., thèmes qui relèvent de la macroéconomie. D'ailleurs, Samuelson et Nordhaus (2005: Preface xxii), s'adressant directement aux étudiants dans la conclusion à leur préface, considèrent bien que le marché concerne l'une et l'autre partie, puisqu'ils leur souhaitent un bon voyage au pays des marchés :

As you begin your journey into the land of markets, ${ }^{1}$ it would be understandable if you are anxious. But take heart. The fact is that we envy you, the beginning student, as you set out to explore the exciting world of economics for the first time. This is a thrill that, alas, you can experience only once in a lifetime. So, as you embark, we wish you bon voyage!

6 Nous étudierons donc la façon dont la notion de marché est présentée, en nous attachant à observer et analyser tout ce qui peut contribuer à la définir, ce qui nous conduira à envisager la notion de définition et de contexte définitoire de manière extensive. Après avoir précisé le choix du corpus, exposé l'arrière plan théorique et méthodologique qui a servi de cadre à cette étude, nous présenterons les premières conclusions fondées sur les résultats de nos observations. Enfin, nous replacerons le problème dans un contexte plus large, en prenant en compte les critiques des défenseurs d'une autre façon de concevoir l'enseignement de l'économie. 


\section{Corpus, cadre théorique et méthodologique}

Le corpus retenu pour cette étude est composé de trois manuels récents, très largement utilisés sur les campus universitaires, et comparables en ce qu'ils constituent une initiation aux principes de l'économie, et sont subdivisés en deux parties, à savoir la microéconomie et la macroéconomie, dans cet ordre. Plus précisément, il s'agit de l'incontournable ouvrage de Paul Samuelson et de William Nordhaus, Economics, dans sa plus récente version à ce jour (18 édition, 2005), de la troisième édition de Principles of Economics de N. Gregory Mankiw (2004), qui connaît également un vif succès, et de la neuvième édition de Richard Lipsey (autre spécialiste des manuels d'économie) et Alec Chrystal (1999). Ces trois manuels comptent respectivement 776, 848 et 640 pages. Tous les auteurs sont ou ont été universitaires: P. A. Samuelson a créé le département d'économie du Massachusets Institute of Technology, dont il est professeur émérite et a été le premier Américain à recevoir un Prix Nobel d'économie en 1970 ; W. Nordhaus enseigne actuellement à l'université de Yale ; N. G. Mankiw enseigne à Harvard; R. G. Lipsey, professeur émérite, poursuit des recherches au sein de l'Université Simon Fraser à Vancouver (Canada) et K. A. Chrystal a enseigné à Londres (City University Business School), ainsi que dans les universités d'Essex, de Manchester et de Sheffield. En outre, tous ces auteurs ont ou ont eu d'autres responsabilités, notamment en qualité de conseillers économiques auprès des présidents J. F. Kennedy (P. Samuelson), Carter (W. Nordhaus), des Banques centrales ou autres institutions majeures (Réserve fédérale de Boston pour N.G. Mankiw, Réserve Fédérale pour P. A. Samuelson, Banque d'Angleterre pour K. A. Chrystal, National Bureau of Economic Research pour N.G. Mankiw, HM Treasury pour K. A. Chrystal). Il est important de donner ces précisions, d'abord parce qu'il devient évident que l'économie n'est pas coupée de la politique et des sphères d'influence, mais aussi pour mieux mettre en perspective ce que nous pourrons dire du discours pédagogique qui est livré aux étudiants.

La présentation de la notion de marché prend de multiples formes dans chacun de ces manuels : afin de mieux analyser le discours qui s'y rattache, nous avons cheminé de l'explicite vers l'implicite, en partant des éléments les plus aisément repérables. De toute évidence, les définitions contenues dans les glossaires et en contexte dans les paragraphes ou chapitres portant directement sur le sujet constituent des éléments clairement identifiables qui nous ont servi de point d'appui. Une lecture attentive des manuels nous a également permis de relever systématiquement toutes les occurrences du terme marché, seul ou en combinaison, tous chapitres confondus, et d'analyser les contextes immédiats de ces occurrences. Par ailleurs, les index plus ou moins exhaustifs des manuels nous ont servi à ébaucher un réseau de notions annexes. Les recoupements entre les données d'ordre terminologique ou phraséologique, les définitions et les index nous ont aidée à vérifier et, le cas échéant, préciser ce réseau. Ceci nous a conduite à élargir notre approche du discours définitoire et à nous rendre compte de sa complexité et de son ambiguïté. Dans la mesure où certaines notions clés entretiennent des relations de complémentarité ou de substituabilité avec la notion de marché, il convenait d'envisager que tout discours sur ces notions puisse être également un discours sur le marché. Dans l'optique qui est la nôtre de mesurer, à terme, l'impact du discours définitoire autour de la notion de marché sur les étudiants, il importait donc de prêter une attention toute particulière aux passages où ce discours 
est le moins visible et où il risque, par voie de conséquence, d'être d'autant plus sournois et efficace dans l'influence qu'il exerce que la vigilance des lecteurs ne sera alors pas mobilisée.

Dans les différentes phases de notre étude, nous avons naturellement eu recours aux outils d'analyse pertinents. Le repérage des termes et phrasèmes, l'établissement des liens entre les notions et la référence à la définition en terminologie ont pour cadre la théorie de la terminologie-phraséologie (Clas 1985, Cabré 1994, 1998, Blanchon 1997). Notre approche de la définition s'est appuyée également sur la valeur de la copule be en linguistique, et l'analyse des aspects rhétoriques du discours a fait appel à la théorie de l'énonciation (Kerbrat-Orecchioni 2002). L'étude plus large de la présentation diffuse du marché dans la totalité des textes prend en compte les aspects idéologiques et sociologiques du discours (Fairclough 2000).

\section{Regards croisés sur les résultats et analyse des observations}

\subsection{Les mentions explicites}

\subsubsection{Définitions et données sur l'axe syntagmatique}

10 La démarche la plus naturelle pour qui cherche à comprendre une notion est de se reporter à sa définition. Les définitions offertes par les manuels sont répertoriées dans le glossaire et sont également incorporées au discours, généralement dans les chapitres ou paragraphes expressément consacrés à la notion.

11 Les trois manuels du corpus offrent les définitions suivantes de market dans leurs glossaires :

An arrangement whereby buyers and sellers interact to determine the prices and quantities of a commodity. Some markets (such as the stock market or a flea market) take place in physical locations; other markets are conducted over the telephone or are organized by computers and some markets now are organized on the Internet. (Samuelson \& Nordhaus $2005: 744$ )

A group of buyers and sellers of a particular good or service. (Mankiw 2004 : 831)

An area over which buyers and sellers negotiate the exchange of a well-defined commodity. (Lipsey \& Chrystal $1999: 620$ )

12 Si les définitions sont reprises à l'identique et intégrées dans le corps des textes par tous les auteurs, Samuelson et Nordhaus, quant à eux, apportent en complément une définition légèrement différente dans leur chapitre 2 (p. 26) :

A market is a mechanism through which buyers and sellers interact to determine prices and exchange goods and prices.

13 Ces différentes définitions appellent immédiatement un certain nombre de remarques. Le premier point qui ressort de leur lecture est que la dénomination «marché » est une figure de style. En effet, le marché, tel qu'il est compris en économie, n'a plus grand chose à voir avec un endroit précis, même si, dans leur glossaire, Lipsey et Chrystal définissent market par area, puisque cet espace peut être virtuel, comme le soulignent Samuelson et Nordhaus. On notera d'ailleurs que les auteurs des manuels ont recours à la métonymie en créant une équation entre market et arrangement ou mechanism pour Samuelson et Norhaus et market et group pour Mankiw. Ce choix propre à chaque auteur nous conduit à réfléchir à la nature, au rôle et à l'impact potentiel de la définition dans 
les manuels de manière générale : très souvent, les manuels sont considérés comme la somme des connaissances sur un sujet donné et le résultat d'un consensus. Les définitions, en particulier, par leur caractère officiel et leur style apparemment neutre ne sauraient être remises en cause par les étudiants. Or, par le simple fait d'établir une équation au moyen d'une copule explicite dans le corps du texte (Le marché est...) ou implicite dans le glossaire (marché : ...), l'auteur d'une définition est obligatoirement amené à opérer un choix des traits sémiques qu'il juge les plus pertinents, au détriment d'autres traits, laissés dans l'ombre. Au même titre que la métaphore, la métonymie éclaire un aspect particulier et, parce qu'elle laisse dans l'ombre bien d'autres traits, elle peut être l'occasion d'une présentation subjective d'une notion. La définition est donc, en puissance, un moyen d'influencer le public qui en prend connaissance et la mémorise, sans la remettre en question, dans la mesure où les auteurs des manuels font autorité quant au lexique et à la syntaxe, comme le souligne Kuhn (1970:136): "textbooks themselves aim to communicate the vocabulary and syntax of a contemporary scientific language ».

Le second point de comparaison entre les définitions des trois manuels en question fait ressortir que le marché, dans tous les cas, met en présence des acheteurs et des vendeurs, et qu'il implique une interaction ou une négociation entre ces acteurs. Autant dire que ces définitions, dont les éléments sont de toute évidence connus du public, n'apportent pas les informations que l'on pourrait en attendre et n'ont guère d'utilité. En effet, une définition de notion doit prendre la forme d'une définition terminologique (Blanchon 1997), c'est-à-dire qu'elle doit, d'une part, circonscrire la notion, en délimiter les fins (finis), et d'autre part, la replacer dans un système de notions de sorte que l'on puisse comprendre quels liens elle entretient avec les autres notions du domaine (hypéronymes, hyponymes, etc.). Si l'on jette un regard critique sur ces définitions, il ressort que l'impression première est que la dénomination "marché » pourrait constituer une enveloppe, un récipient que chacun pourrait remplir à sa guise au gré des situations, ce qui nous conduit à pousser plus loin l'investigation, afin de vérifier cette hypothèse. Assurément, le terme marché figure soit au singulier soit au pluriel dans les index, sous la forme market(s) et différents types de marchés sont évoqués par la simple lecture de la table des matières des manuels : products markets, factor markets, labor market, financial markets, etc. Samuelson et Nordhaus (p.26) confirment cette diversité dans leur chapitre 2 (Markets and Government in a Modern Economy), juste après la reprise dans le texte de la définition fournie dans leur glossaire :

There are markets for almost everything. You can buy artwork by old masters at auction houses in New York, or pollution permits at The Chicago Board of Trade, or illegal drugs from delivery services in many large cities.

S'adressant à un public d'étudiants, les auteurs devraient adapter leurs définitions à leur public et il est évident que ce n'est pas le cas : les étudiants n'apprennent rien de nouveau à partir des définitions des glossaires ou dans le texte ou encore en marge des textes. Il faut donc chercher à cerner la notion ailleurs.

16 L'examen des différentes entrées des glossaires comportant le terme market en composition est instructif, car il permet de prendre conscience d'un premier réseau de notions officiellement rattachées au marché qui peuvent aider à mieux l'appréhender. Précisons qu'il s'agit de termes à part entière, qui correspondent à des notions définies de manière plus précise. Un recoupement avec les autres occurrences de marché dans 
l'ensemble des chapitres des manuels, dont la liste figure dans le tableau 1 en annexe, permet de compléter ce réseau de notions explicitement associées à la notion de marché sur l'axe syntagmatique. Ainsi, on remarque que les termes équilibre, concurrence, prix, et efficacité entretiennent des liens évidents avec la notion de marché, liens qui sont précisés en contexte, après avoir été annoncés dans les tables des matières, bien souvent: Markets and Economic Efficiency (Samuelson \& Nordhaus, v, 283), Consumers, Producers and the Efficiency of Markets (Mankiw xxviii, 137), Market and competition (Mankiw xxvii, 64), The Market Forces of Supply and Demand (Mankiw xxvii, 63). La notion de l'offre et de la demande, derrière laquelle s'effacent les acteurs du marché, est étroitement liée à l'équilibre ou aux forces du marché, qui viennent en écho à la notion de mécanisme du marché ; on remarquera, au passage, que ces différents termes sont empruntés à la science physique, même si leur origine métaphorique est oubliée, tant ils sont fréquemment employés :

Supply and demand are the two words that economists use most often - and for good reason. Supply and demand are the forces that make market economies work. [...] [This chapter] shows how supply and demand determine prices in a market economy and how prices, in turn, allocate the economy's scarce resources. (Mankiw 63)

The dictionary defines the word equilibrium as a situation in which various forces are in balance - and this describes a market's equilibrium. The equilibrium price is sometimes called the market-clearing price because at this price, everyone in the market has been satisfied (Mankiw 76).

Supply and demand interact to produce an equilibrium price and quantity, or a market equilibrium. [...] (Samuelson \& Nordhaus 54).

[...] We also know that a competitive market is a mechanism for producing equilibrium [...] if we fail to understand the nature of economic equilibrium, we cannot hope to understand the way that different forces affect the marketplace. (Samuelson \& Nordhaus 57)

Prices coordinate the decisions of producers and consumers in a market. Prices are the balance wheel of the market mechanism. (Samuelson \& Nordhaus 27)

17 Les glossaires, comme le corps des textes, confirment également l'importance de la notion d'économie de marché.

A market economy is one in which individuals and private firms make the major decisions about production and consumption (Samuelson \& Nordhaus 8)

18 Au simple niveau de la terminologie et de la phraséologie, le marché est clairement associé à un type d'économie, de structure, d'organisation, de système. Ceci se vérifie dans le corps du texte des manuels et il est important, pour mieux comprendre comment la notion de marché est présentée, de prendre en compte le cadre général qui sert à l'introduire.

\subsubsection{Cadre et organisation de la présentation du marché}

19 Bien qu'il s'agisse d'une notion centrale, elle est souvent précédée d'un exposé plus général des problèmes économiques en termes de rareté des ressources et de nécessité d'une utilisation efficace. Ces deux thèmes conduisent à poser la question des choix, de l'offre et de la demande à satisfaire. Dès lors, le marché peut être présenté comme la réponse aux problèmes posés. Dans les dernières éditions de leurs manuels, les auteurs ont fait le choix de tendre une toile de fond historique avant d'aborder la notion de marché ; ils soulignent que l'histoire récente a montré le triomphe de l'économie de marché sur tout autre système : 
[...] within the last two decades of the century, governments of one communist country after another abandoned their central planning apparatus . More and more economic transactions and activities were then left to be regulated by the selforganizing system of the market. Seldom has a great social issue been settled with such conclusiveness.

Adam Smith was right and Karl Marx was wrong. (Lipsey \& Chrystal 2)

A decade ago, economic revolutions in Eastern Europe, in the former Soviet Union, in China, and elsewhere tore those societies apart. Young people battered down walls, overthrew established authority, and agitated for democracy and a market economy because of discontent with their centralized socialist governments. Students like ourselves are marching, and even going to jail, to win the right to study radical ideas and learn from Western textbooks like this one in the hope that they may enjoy the freedom and economic prosperity of democratic market economies. (Samuelson \& Nordhaus, Preface xxi)

The collapse of communism in the Soviet union and Eastern Europe in the 1980s may be the most important change in the world during the past half century. [...] today, most countries that once had centrally planned economies have abandoned this system and are trying to develop market economies. (Mankiw 9)

Que le rappel historique soit exposé en termes triomphateurs ou de manière plus neutre, le fait est que l'économie de marché n'a désormais plus d'alternative. Il est clair qu'elle a pour conditions la liberté et la démocratie, et pour résultat la croissance et la prospérité. La notion de marché s'inscrit dans un système bien défini, le système concurrentiel qui semble avoir pour cadre privilégié le capitalisme. La victoire du capitalisme est d'ailleurs clairement résumée dans l'équivalence terminologique établie explicitement par Samuelson et Nordhaus (p.25): «[...] Markets, or what we call the "market mechanism" or "competitive capitalism" ".

Après avoir replacé le marché dans le cadre d'un choix de système politique et de société (market society), les auteurs continuent leur présentation par une référence à la Main Invisible d'Adam Smith ${ }^{2}$. Samuelson et Nordhaus parlent d'un miracle, Mankiw de magie et Lipsey et Chrystal, qui préfèrent la formulation " hidden hand », évoquent « an amazing emergence of order $»$. Les uns citent directement le passage de la Richesse des Nations le plus communément évoqué (Samuelson \& Nordhaus, p. 25 ; Lipsey \& Chrystal, p.1). Mankiw, pour sa part, choisit de commenter la métaphore de Smith lorsqu'il aborde pour la première fois la notion de marché dans son premier chapitre qui énonce les 10 principes de l'économie. Le principe ${ }^{\circ} 6$ (p. 9-10) a pour titre " Markets are usually a good way to organize economic activity» :

In his 1776 book An Inquiry into the Nature and Causes of the Wealth of Nations, economist Adam Smith made the most famous observation in all of economics: Households and forms interacting in markets act as if they are guided by an "invisible hand" that leads them to desirable market outcomes. One of our goals in this book is to understand how this invisible hand works its magic. As you study economics, you will learn that prices are the instrument with which the invisible hand directs economic activity.

[...] There is an important corollary to the skill of the invisible hand in guiding economic activity: When the government prevents prices from adjusting naturally to supply and demand, it impedes the invisible hand's ability to coordinate the millions of households and firms that make up the economy. [...] This corollary [...] explains the failure of communism. In communist countries, prices were not determined in the marketplace but were dictated by central planners; these planners lacked the information that gets reflected in prices when prices are free to respond to market forces. Central planners failed because they tried to run the 
economy with one hand tied behind their backs - the invisible hand of the marketplace.

\subsubsection{Définition par contrastes}

22 Le marché se définit aussi par rapport à ce qu'il n'est pas. Dans les définitions précédentes, il est opposé à l'économie planifiée de type soviétique, mais également à quelque ingérence de l'État de manière générale, comme l'indique également l'opposition entre les lois dictées par l'offre et de la demande, et celles qui sont imposées par un gouvernement :

The economy is governed by two kinds of laws : the laws of supply and demand and the laws enacted by governments. (Mankiw 131).

Le marché est donc opposé à la notion de centralisation, comme à celle de chaos : à la question rhétorique What is a market?, Samuelson et Nordhaus répondent clairement, Not chaos, but economic order (p. 26).

24 L'examen des listes du tableau 1, en annexe, met en évidence un certain nombre de contrastes. En effet, les termes à connotation positive y côtoient des notions négatives telles que les imperfections, l'inefficacité, le déséquilibre, et même les échecs du marché. Les termes négatifs renvoient à des situations qui ne sont pas souhaitables et qu'il faut éviter en tendant vers l'idéal d'efficacité et d'équilibre, l'idéal du marché parfait. Le recours à la main visible de l'État ne s'explique que faute de mieux. C'est d'ailleurs la Main Invisible qui est mise à contribution pour aborder le délicat problème ; si elle peut faire des merveilles dans une situation de concurrence parfaite, dès lors qu'il y a concurrence imparfaite pouvant conduire à une situation de monopole, par exemple, ou à des retombées négatives telles que la pollution, ou des inégalités insupportables, une intervention du gouvernement est envisagée :

[...] markets do not always lead to the most efficient outcome. One set of market failures concerns monopolies and other forms of imperfect competition. A second failure of the "invisible hand" comes when there are spillovers or externalities outside the marketplace. [...] A final reservation comes when the income distribution is politically or ethically unacceptable. When any of these elements occur, Adam Smith's invisible hand doctrine breaks down and government may want to step in to mend the flawed invisible hand. (Samuelson \& Nordhaus 29) Markets do many things well, but they do not do everything well. (Mankiw 203) The invisible hand is powerful but not omnipotent. [...] When people cannot solve the problem of externalities privately, the government often steps in. Yet, even now, society should not abandon market forces entirely. [...] Market forces, properly redirected, are often the best remedy for market failure. (Mankiw 217)

Il est toutefois clair que la reconnaissance de ces dysfonctionnements du marché n'aboutit pas à faire l'apologie de l'intervention de l'État. La norme reste « a competitive market free of government regulation » (Mankiw, p. 114).

\subsubsection{Recours à la métaphore}

Outre les emprunts déjà mentionnés au domaine de la physique au niveau même de la dénomination des notions (forces, équilibre, mécanisme, frictions), la métaphore est assez fréquente dans le discours de présentation du marché à travers les trois ouvrages.

Si l'on s'intéresse aux verbes qui sont étroitement associés au marché (tableau 2, en annexe), on s'aperçoit que le recours à la métaphore a pour effet de personnifier le marché qui agit, organise, accomplit des choses. Il apporte la solution à des problèmes, 
assure coordination et équilibre. Il joue un rôle moral, puisqu'il guide, dirige et récompense. Les phrasèmes, qui mentionnent la discipline du marché, le comportement du marché, ses vertus et ses failles vont dans le sens de cette présentation imagée d'un marché acteur.

Du marché acteur au marché théâtre, il n'y a qu'un pas aisément franchi par Lipsey et Chrystal (p. 35) :

[individuals, firms, and government] are the dramatis personae of economic theory, and the stage on which their play is enacted is the market.

La théâtralité du marché trouve un écho dans la métaphore choisie par Mankiw (p. 84) de la Main Invisible, chef d'orchestre, qui tient la baguette du système des prix avec laquelle elle dirige l'orchestre économique.

If market economies are guided by an invisible hand, as Adam Smith famously suggested, then the price system is the baton that the invisible hand uses to conduct the economic orchestra. (ch 4 : The Market Forces of Supply and Demand)

On notera, par ailleurs, que le marché est doué d'une intelligence supérieure, et qu'aucun ordinateur, aussi puissant fût-il, ne saurait rivaliser avec lui :

Without central intelligence or computation, it solves problems of production and distribution involving billions of unknown variables and relations, problems that are far beyond the reach of even today's fastest supercomputer. (Samuelson \& Nordhaus 26)

Enfin, c'est aussi par le biais de la métaphore que les auteurs peuvent faire passer une contradiction interne dans leur présentation du marché. Après avoir insisté sur l'échec de l'économie centralisée et planifiée, Mankiw n'hésite pas à reprendre les termes planner et même dictator, en les colorant différemment : finalement, le marché est une sorte de centralisateur des informations. À nouveau, on notera le recours à la personnification : c'est en quelque sorte un Big Brother omniscient et omnipotent qui nous est présenté dans le paragraphe sur market efficiency, mais, fort heureusement, un Big Brother bienveillant ou, le cas échéant, un redresseur de torts économiques à la Robin des Bois :

The benevolent social planner is our all-knowing, all powerful, well-intentioned dictator. The planner wants to maximize the economic well-being of everyone in society. (Mankiw p. 147)

[...] In addition to efficiency, the social planner might also care about equity - the fairness of the distribution of well-being among the various buyers and sellers. The benevolent social planner doesn't need to alter the market outcome because the invisible hand has already guided buyers and sellers to an allocation of the economy's resources that maximized total surplus (Mankiw, p. 150)

Ainsi, aussi paradoxal que cela puisse paraître lorsqu'on se réfère à l'idée d'un marché décentralisé, la notion de planificateur est incorporée à la définition du marché, avec l'idée que non seulement le marché remplace le planificateur, mais qu'il réussit mieux que lui.

\subsection{Le discours implicite}

\subsubsection{L'axe paradigmatique (substituabilité)}

En nous référant au tableau 1 (en annexe), nous avons évoqué les liens évidents entre le marché et certaines notions (prix, concurrence, équilibre, efficacité, offre et demande, etc.) et ceux-ci ont été confirmés par l'étude des contextes. Un examen plus approfondi, 
effectué à partir des notions de coordination entre l'offre et la demande et de distribution des ressources, soulève la question suivante: s'agit-il de notions de complémentarité, ou de substituabilité? On a nettement l'impression que, implicitement, ces notions peuvent se recouvrir totalement dans certains cas, mais seulement partiellement dans d'autres. En effet, les contextes suivants laissent à penser que c'est la Main Invisible du marché, ou bien le marché, ou encore les forces de l'offre et de la demande qui procèdent à l'allocation des ressources. Par voie de conséquence, on peut conclure que la Main Invisible fait référence à une extension du marché (appendice), ou au marché dans sa totalité (corps tout entier). Par ailleurs, la coordination est assurée tour à tour par les prix, ou la Main Invisible, ou encore par le marché...

The invisible hand of the market acts to allocate resources efficiently (Mankiw 429).

We examined how markets allocate scarce resources with the forces of supply and demand (Mankiw 203)

In a pure market economy [...] markets determine all resource allocation and income distribution. (Lipsey \& Chrystal 11)

Prices coordinate the decisions of producers and consumers in a market. (Samuelson \& Nordhaus 27)

The price system works to co-ordinate with relative efficiency the decentralized decisions made by private consumers and producers. (Lipsey and Chrystal 2)

Many countries have abandoned the heavy-handed interventionism of government command and regulation for the subtle coordination of the invisible hand. (Samuelson \& Nordhaus 158)

By determining the equilibrium prices and quantities, the market allocates or rations out the scarce goods of the society among the possible uses. (Samuelson \& Nordhaus 59)

Il s'ensuit que, sur l'axe paradigmatique, peuvent apparaître, au fil du discours, un certain nombre de notions qui doivent retenir notre attention puisque, chaque fois qu'elles sont mentionnées, c'est en puissance un discours sur le marché qui est tenu.

\subsubsection{Les termes associés dans les index}

Pour compléter le réseau notionnel, un examen des index de chaque manuel s'impose, qui rappelle les entrées principales à partir du terme " marché », mais surtout indique les entrées secondaires (tableau 3, en annexe), confirmant ainsi certains liens. Si l'on peut s'étonner de la différence marquée dans le nombre des entrées primaires et secondaires selon les manuels, on se rend vite compte à la lecture du contenu des manuels que les éléments présents dans la liste la plus longue sont également mentionnés ici ou là dans les autres manuels, même s'ils ne sont pas répertoriés dans l'index correspondant. Pour ne citer que quelques exemples, la Main Invisible de Smith est bien abordée dans les trois manuels, de même que les notions de division du travail et de spécialisation. En réalité, tous les éléments des trois listes sont présents dans les trois manuels, de sorte que nous pouvons considérer que l'ensemble des notions relevées dans le tableau 3 (en annexe) constitue un réseau complémentaire de notions permettant de jeter un autre regard sur la présentation du marché. Là encore, chaque fois que l'une des notions mentionnées est abordée, on se doit d'être particulièrement vigilant car le discours qui s'y réfère est également un discours en relation avec le marché. On prend davantage conscience de l'omniprésence de la notion, qui concerne aussi bien l'innovation, les progrès technologiques, l'emploi, les syndicats, que la mondialisation, les marchés financiers, les fusions et acquisitions, la pollution, les 
droits de propriété, etc. Si les auteurs ont présenté le marché dans la partie "microéconomie ", dans laquelle il était objet explicite de l'étude, il s'avère que, par glissement et in absentia, le marché devient outil pour étudier les aspects macroéconomiques. Cette dispersion de la notion de marché sur l'ensemble des chapitres contribue à faire passer l'idée que le marché est le moyen incontournable pour poser et essayer de résoudre au mieux tous les problèmes économiques. Elle a également pour effet d'accorder à la notion une certaine élasticité, qui laisse une impression de flottement et de flou: on oscille, en effet, entre un marché idéal, de concurrence parfaite, libre de toute ingérence de l'État et un marché qui ne peut tout résoudre et a besoin de l'intervention de l'État pour réduire ses imperfections. Est-ce à dire que les auteurs s'efforcent d'être objectifs afin de laisser les étudiants faire la juste part des choses et tirer leurs propres conclusions? C'est ce que nous nous proposons de déterminer dans la discussion qui suit sur l'impact possible du discours de présentation du marché sur les étudiants qui sont pour la première fois confrontés à l'étude des grands principes économiques.

\section{Discussion}

Les récentes éditions sur lesquelles nous avons travaillé mettent en avant les nouveaux aspects ajoutés depuis l'édition précédente :

Farm economics, labor unions, Marxian economics, the lump-of-labor fallacy, and health economics have been trimmed to make room for environmental economics, network economics, real business cycles, and financial economics. (Samuelson \& Nordhaus, Preface xviii)

Parmi les nouveaux thèmes abordés ou développés, on note, chez Lipsey et Chrystal, entre autres modifications, une révision complète du chapitre sur la politique économique, pour tenir compte des situations d'échec du marché. On remarque chez Samuelson et Nordhaus, comme chez Mankiw, l'introduction de la notion de behavioral economics, liée au souci de suggérer que les choix des gens ne sont pas toujours rationnels. Les trois manuels comprennent une application plus large de la théorie des jeux, insistent à maintes reprises sur le fait que nous ne sommes pas dans un monde idéal, que la concurrence parfaite n'existe pas. Ils mentionnent également les notions d'asymétrie de l'information, les cas d'inefficacité ou d'imperfections du marché.

Il convient toutefois de souligner que, tout en annonçant que l'économie s'est ouverte à d'autres sujets comme l'environnement, l'art, la discrimination sexuelle ou raciale, etc., Samuelson et Nordhaus maintiennent que « the flag of economics flies over the traditional territory of the marketplace » (Preface xviii). La question que nous sommes donc en droit de nous poser est de savoir si nous pouvons lire dans ces changements un réel désir d'ouvrir la présentation de l'économie à de nouveaux points de vue. Certes, nous ne pouvons ignorer que les auteurs admettent explicitement l'existence d'approches différentes, voire de dissensions :

One of the major obstacles to understanding modern economics is the proliferation of contesting schools of macroeconomics. [...] While many people fret about the divisiveness of modern macroeconomics, we think it is a sign of health and prefer lively debate to complacent consensus. (Samuelson \& Nordhaus, Preface xix)

Mais cette prise en compte de la diversité est restreinte à la macroéconomie, et demeure toute relative. En effet, Samuelson et Nordhaus ne laissent-ils pas entendre 
dans leur préface que, dans un monde qui évolue très rapidement, il est possible de garder des repères en s'appuyant sur des notions qui ont fait leurs preuves?

Often, economics appears to be an endless procession of new puzzles, problems, and dilemmas. But as experienced teachers have learned, there are a few basic concepts that underpin all of economics. Once these basic concepts have been mastered, learning is much quicker and more enjoyable. We have therefore chosen to focus on the central core of economics - on those enduring truths that will be just as important in the twenty-first century as they were in the twentieth ${ }^{3}$.(Preface xvii)

De son côté, Mankiw annonce que sa nouvelle édition s'est enrichie par nécessité et a été réactualisée au vu des évolutions qui ont eu lieu dans le monde réel depuis l'édition précédente :

Much has happened in the world since I wrote the last edition of this book. Over the past few years, another U. S. recession, a new president, a tax cut, corporate accounting scandals, a new European currency, and terrorist attacks have all altered the economic landscape. Because the teaching of economics has to stay current with an ever changing world, this new edition includes dozens of new case studies and boxes. (Preface vii)

41 Toutefois, à la lecture de la dernière phrase de cette citation, on peut s'interroger sur le décalage évident par rapport à la phrase précédente. En effet, si la nouvelle édition de Mankiw consiste seulement à ajouter des études de cas et à réactualiser les statistiques, le changement n'est pas aussi important qu'il le devrait pour prendre en compte les nouvelles réalités et, sans aucun doute, les résultats des nouvelles recherches en économie. Nous ne pouvons nous empêcher de nous demander si ces changements ne constituent pas plutôt, du moins pour les deux manuels les plus récents, une réponse tactique aux critiques qui se font de plus en plus entendre par la voix du mouvement " post-autiste ${ }^{4}$. Il convient donc de replacer notre discussion dans un contexte plus large.

Avant toute chose, une brève présentation du mouvement, de ses positions et revendications s'impose, qui nous aidera à mieux appréhender la situation. Ce mouvement compte environ 22000 membres aux États-Unis, regroupés au sein de "The American Economic Association», qui œuvre pour le pluralisme en matière d'économie. Au plan international, une Confédération Internationale rassemble une trentaine de groupes. Bien que les approches des divers mouvements soient variées, ils ont pour caractéristique commune de s'opposer à l'approche orthodoxe du néoclassicisme. Au cours des dernières années, les revendications ont été exprimées de manière répétée et soutenue. La France a donné le ton en 2000, sous la forme d'une pétition sur Internet rédigée par des étudiants des grandes écoles pour dénoncer le contenu de l'enseignement actuel, traditionnel, de l'économie et les préoccupations et méthodes des chercheurs, leur reprochant de s'intéresser à un monde irréel, d'où l'accusation d'autisme. De leur côté, 200 économistes français accusèrent l'orthodoxie rationaliste qui oubliait que l'Homo economicus pouvait ne pas être toujours prévisible et raisonnable. Des échos se firent entendre en Grande-Bretagne, en juin 2001, lorsque 27 doctorants de Cambridge lancèrent leur propre pétition, intitulée "Opening Up Economics " pour faire écho aux doléances des Français en insistant sur les problèmes posés en matière de recherche. De manière générale, l'approche dominante était accusée de tout rapporter à des modèles mathématiques et de ne pas assez prendre en compte les questions sociales qui avaient été à l'origine des travaux des premiers grands économistes. En août 2001, les étudiants de dix-sept pays se retrouvèrent à Kansas City où ils rédigèrent une lettre à l'intention des différents départements 
d'économie des universités pour demander une réforme de l'enseignement et de la recherche qui tiendrait compte de la nouvelle approche. En mars 2003, ce fut le tour des étudiants de Harvard de demander par pétition que leur université offre un cours d'introduction à l'économie qui permette aux étudiants de développer un esprit critique.

À la lumière des critiques exprimées par les défenseurs d'une vision hétérodoxe de l'économie, un certain nombre de questions concernant la présentation du marché par les trois manuels qui nous intéressent peuvent se poser. En dépit des allusions ici ou là à des interprétations différentes selon les économistes, la vision d'ensemble qui est donnée est une image lissée, qui laisse supposer un consensus, avec, le cas échéant, des différences mineures, ce qui laisserait entendre que la discipline répond aux critères d'une science dure (Klamer 1990); la présentation consiste à faire en sorte que les notions s'enchaînent, s'entrelacent selon une suite raisonnée qui semble d'une grande logique. Le même raisonnement est systématiquement appliqué à de nombreux sujets, tous chapitres confondus. Dès qu'il s'agit d'optimiser les bénéfices, l'analyse des coûts et des bénéfices est mise en œuvre, et les courbes de l'offre et de la demande permettent d'établir où se situe le point d'équilibre pour assurer la plus grande efficacité. Cette répétition du même type d'analyse peut s'interpréter comme un choix rhétorique. On se rend compte que le marché demeure la clé de voûte de l'ensemble.

Ormerod (2005: 43) fait remarquer que les manuels d'introduction à l'économie font penser aux manuels pour ingénieurs, c'est-à-dire qu'ils donnent nettement l'impression que tous les problèmes ont été résolus ou peuvent l'être, de sorte que les étudiants n'ont plus qu'à ingérer et accepter une masse de connaissances établies. Ainsi, comme le souligne Stiglitz (2002), la théorie continue de reposer sur l'idée de la maximisation des bénéfices alors que Daniel Kahneman et Vernon Smith, lauréats 2002 du Prix Nobel d'économie, ont apporté la preuve que les agents économiques agissent rarement de la manière rationnelle décrite par la théorie économique standard et qu'ils ne cherchent pas systématiquement à maximiser leurs gains. Pour Mayhew (2005: 56), insister, comme le font Mankiw et ses collègues, sur les actions individuelles qui seraient ensuite mises en relation par les forces de l'offre et de la demande revient à dire que seules les forces du marché, donc le marché, peuvent agir. C'est ignorer le contexte social et culturel et oublier que les économies sont le fait des hommes, qui votent des lois et des règles de manière collective; les agents économiques doivent donc être replacés dans le contexte culturel, historique et institutionnel qui est le leur. Ces systèmes peuvent être changés lorsqu'ils montrent leurs limites, et il n'y a donc pas de fatalité. Si les étudiants ne sont pas encouragés à réfléchir aux problèmes en ces termes, ils ne leur reste qu'à accepter passivement la « loi du marché » sans la remettre en question. Selon Benicourt (2005: 89), les manuels n'expliquent pas comment les prix sont fixés; ils émergent de la confrontation de l'offre et de la demande, comme par miracle, le miracle du marché ou de la Main Invisible. Les auteurs des manuels posent la question, mais apportent une seule réponse, sans véritable explication: c'est le marché qui fixe les prix.

Let us now take stock of what the market mechanism accomplishes. By determining the equilibrium prices and quantities, the market allocates or rations out the scarce goods of the society among the possible uses. Who does the rationing? A planning board? Congress? The President? No. The marketplace, through the interaction of supply and demand, does the rationing (Samuelson \& Nordhaus 59). 
Par souci de clarté, ils fournissent des exemples empruntés, il est vrai, à la vie quotidienne, mais ces exemples sont extrêmement réducteurs, comme le sont les modèles mathématiques, de sorte qu'ils ne permettent pas de se rendre compte de ce qui peut se passer dans la réalité sur un marché. Quand Mankiw évoque le marché des glaces dans une ville donnée (pp. 65 et sq.), il suppose que les acheteurs sont " preneurs de prix » et il évoque simplement du côté des vendeurs, un prix « courant», sans plus d'explication. Il s'agit là d'un postulat. D'une certaine manière, on pourrait dire que, forts de l'échec de l'économie centralisée de type soviétique, qui signe la victoire de l'économie de marché, les auteurs attendent des étudiants un acte de foi : puisqu'il n'y a pas d'alternative actuellement, faute de mieux, il faut accepter le marché et croire en l'économie de marché. Quand bien même le marché montre ses limites et ses imperfections, ces dernières sont jugées par rapport à la norme qui est le marché idéal de concurrence parfaite et d'équilibre.

Le discours sur le marché est bien plus qu'un discours strictement économique. Il est étroitement lié à un discours sur un type de société libérale et démocratique, ouverte sur le reste du monde, qui, parce qu'elle assure croissance, stabilité, et prospérité, a fait ses preuves de manière indiscutable :

You often hear that imitation is the sincerest form of flattery. In economics, imitation occurs when a nation adopts another nation's economic structure in the hope that it will produce growth and stability. In the last fifteen years, country after country threw off the shackles of communism and stifling central planning not because the textbooks convinced them to do so, but primarily because they could see how the market-oriented countries of the West prospered while the command economies of the east collapsed. (Samuelson \& Nordhaus 639)

La notion de marché concurrentiel, garant de la prospérité, et ayant pour prérequis la liberté est également très présente dans le discours sur le commerce international et les passages sur la mondialisation, les activités des entreprises, la délocalisation. On se rend compte que le discours de présentation du marché est omniprésent et peut grandement influencer les esprits en matière de politique économique, de gestion des entreprises, et d'aide aux économies en voie de développement, pour ne citer que quelques exemples. Fairclough $(2000: 147)$ montre que le discours de la théorie néolibérale dépasse, bien évidemment, le contexte des manuels, mais il convient de souligner que l'on y retrouve les notions clés attachées à la notion de marché telle qu'elle est présentée dans les trois manuels étudiés :

This discourse includes a narrative of progress: the 'globalized' world offers unprecedented opportunities for 'growth' through intensified 'competition', but requiring unfettered 'free trade' and the dismantling of 'state bureaucracy' and 'unaffordable' welfare programmes, 'flexibility' of labour, 'transparency', 'modernization' and so forth. This discourse projects and contributes to actualizing new forms of productive activity, new social relations, new forms of identity, new values, etc.

\section{Conclusion}

Il est intéressant, pour terminer, de prendre conscience du fait que, puisqu'il y a un marché pour tout, il y a également un marché des idées, et que, précisément, ce sont les manuels d'économie qui suivent les normes actuelles des idées reçues en matière d'économie qui ont les plus grandes chances d'être choisis par la majorité comme support de l'enseignement sur les campus. Les auteurs, à travers les enseignants, 
perpétuent ainsi une vision traditionnelle. Des générations d'étudiants sont alors formées à considérer la notion de marché comme la réponse la plus efficace aux problèmes économiques de la rareté des ressources et de leur meilleure allocation possible. Les forces du marché des idées parviendront-elles à rétablir un équilibre entre la norme actuelle, l'orthodoxie économique, et une vision plus riche, hétérodoxe, laissant la place à d'autres présentations de la notion de marché ? Cette étude préliminaire demande à être poursuivie et approfondie pour envisager une réponse à cette question. Il nous faudra analyser la présentation de la notion de marché et la place qui lui est réservée à travers d'autres manuels, dont les auteurs ont une autre vision du monde de l'économie et souhaitent susciter une réflexion personnelle chez les étudiants. Nous pensons en premier lieu à un précurseur, Linder (1977), qui a pris très tôt le contre-pied de Samuelson par le biais de son Anti-Samuelson au titre évocateur, mais aussi à Stiglitz, ou encore Bober (2001), Keen (2002) et Krugman, dont le dernier manuel Economics devait sortir en janvier 2006, au moment où ce travail a été mené.

L'intérêt de cette première étude est de nous avoir permis d'envisager la définition sous un angle plus large, et d'avoir pu compléter les informations rassemblées sur l'axe syntagmatique par les données fournies sur l'axe paradigmatique. D'une part, nous avons montré qu'une notion se définit en positif et négatif, c'est-à-dire par ce qu'elle est aussi bien que par ce qu'elle n'est pas, de manière explicite. D'autre part, en l'absence d'une définition de type terminologique, nous avons cherché à obtenir des indications supplémentaires en nous intéressant à l'axe paradigmatique, et cela nous a permis de déterminer quelles notions peuvent se substituer à la notion de marché et l'éclairer. Le discours définitoire doit donc être conçu de manière extensive, en prenant en compte non seulement les manifestations évidentes, mais également les aspects moins visibles par le biais des équivalences et rapprochements possibles repérés dans les textes. Nous avons pu mettre en relief le changement de perspective par rapport au marché entre la partie consacrée à la microéconomie, et celle réservée à la macroéconomie. D'objet d'étude, le marché est devenu outil d'analyse, traduisant ainsi l'officialisation de la notion introduite dans la première partie, ce qui rend la remise en cause quasiment impossible. Myers (1992) souligne que les manuels ont tendance à réifier et codifier ce qu'ils avancent comme s'il s'agissait de faits avérés. Swales (2002: 224) résume bien le problème :

[...] the better textbooks are at transmitting a canon of knowledge, the worse they are at fostering critical reading.

Le marché, érigé en référence, est le prisme à travers lequel tous les autres problèmes sont abordés et, si l'on se place du point de vue des critiques, c'est sans doute par le biais de ce discours plus diffus qu'il est plus facile d'influencer un public novice à son insu.

\section{BIBLIOGRAPHIE}

Sources primaires 
Lipsey, R. G. \& K. A Chrystal. 1999. Principles of Economics, $9^{\mathrm{e}}$ édition. Oxford : Oxford University Press.

Mankiw, N. G. 2004. Principles of Economics, $3^{\mathrm{e}}$ édition. Thomson Southwestern.

Samuelson, P. A. \& W. D. Nordhaus. 2005. Economics, $18^{\mathrm{e}}$ édition. Columbus, OH : McGraw-Hill Irwin.

\section{Références}

Benicourt, E. 2005. « Five pieces of advice for students studying microeconomics ». In Fullbrook, E. (dir.), A guide to What's Wrong With Economics. Londres : Anthem Press, 84-94.

Blanchon, E. 1997. «Point de vue sur la définition ». Meta 42/1, Presses de l’Université de Montréal, 168-173.

Bober, S. 2001. Alternative Principles of Economics. Armonk, NY : M. E. Sharpe.

Cabré, M.-T. 1994. «Terminologie et dictionnaire ». Meta 39/4, Presses de l’Université de Montréal, 589-597.

Cabré, M.-T. 1998. La terminologie.Paris : Armand Colin.

Clas, A. 1985. Guide de recherche en lexicographie et terminologie. Paris : Agence de coopération culturelle et technique.

Fairclough N. 2000. « Language and neo-liberalism ». Discourse \& Society 11, 147-148.

Keen, S. 2002. Debunking Economics: The Naked Emperor of Social Sciences. Richmond, Australie : Hyde Park Press.

Kerbrat-Orecchioni, C. 2002). L'énonciation. Paris : Armand Colin.

Klamer, A. 1990. « The textbook presentation of economic discourse ». In Samuels W. J. (dir.), Economics as Discourse. Boston : Kluwer Academic Publishers.

Kuhn, T. S. 1970. The Structure of Scientific Revolutions, $2^{\mathrm{e}}$ édition. Chicago, IL : University of Chicago Press.

Linder, M. C. \& J. Sensat. 1977. Anti-Samuelson (2 volumes). New York : Urzen Books.

Mayhew, A. 2005. « Where do economies come from? The missing story ». In Fullbrook, E. (dir.), A guide to What's Wrong With Economics. Londres : Anthem Press, 47-56.

Myers, G. 1992. « Textbooks and the sociology of scientific knowledge ». English for Specific Purposes 11, 3-17.

Nasar, S. 1995. « Hard act to follow?" ». New York Times, édition du 14 mars, C1 et C8.

Nelson, R. H. 2001. Economics as religion: From Samuelson to Chicago and Beyond. University Park, PA : Penn State University Press.

Ormerod, P. 2005. « Neoclassical economic theory: A special and not a general case ». In Fullbrook, E. (dir.), A guide to What's Wrong With Economics. Londres : Anthem Press, 41-46.

Resche, C. 2005. « Réflexions à partir d'une métaphore banalisée en économie : la 'Main Invisible' d'Adam Smith. Leçons et perspectives ». In M-H Fries (dir.), Collection Travaux 20.25. Bordeaux : Université Bordeaux 2, 57-76.

Skousen, M. 1997. « The perseverance of Paul Samuelson's economics ». Journal of Economic Perspectives 11/2, 145-157. 
Stiglitz, J. 2002. « There is no Invisible Hand ». The Guardian, 20 décembre, consulté le 10/12/2005 $<$ http://www.guardian.co.uk>.

Swales, J. 2002. « The paradox of value: six treatments in search of the reader ». In W. Henderson, T. Dudley-Evans \& R. Backhouse (dir.), Economics as Language, Londres : Routledge, 223-239.

\section{ANNEXES}

Tableau 1. Tableau des occurrences contenant le terme marché dans le texte des manuels

\begin{tabular}{|l|l|l|}
\hline SAMUELSON \& NORDHAUS & MANKIW & LIPSEY \& CHRYSTAL \\
\hline
\end{tabular}




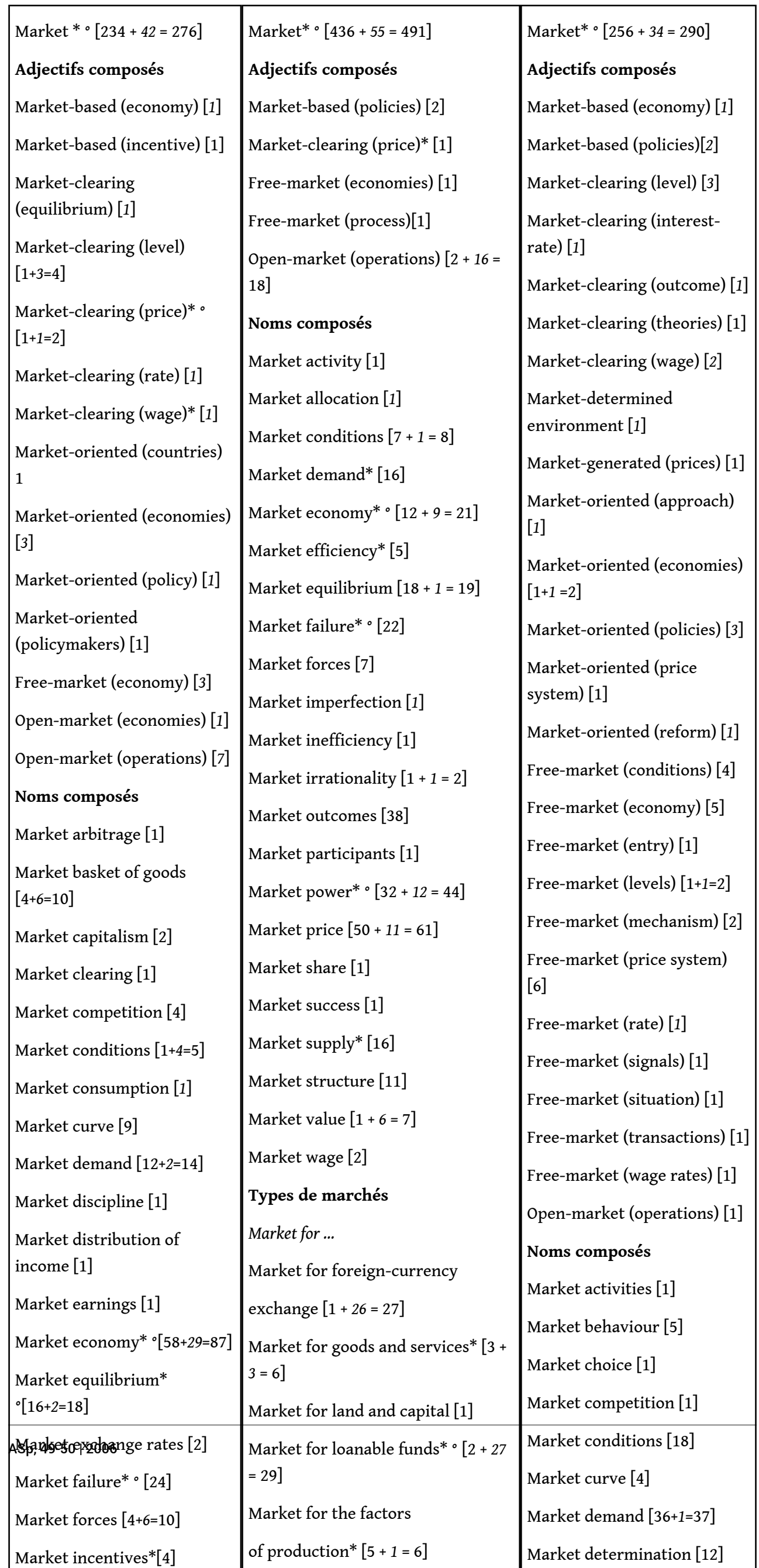




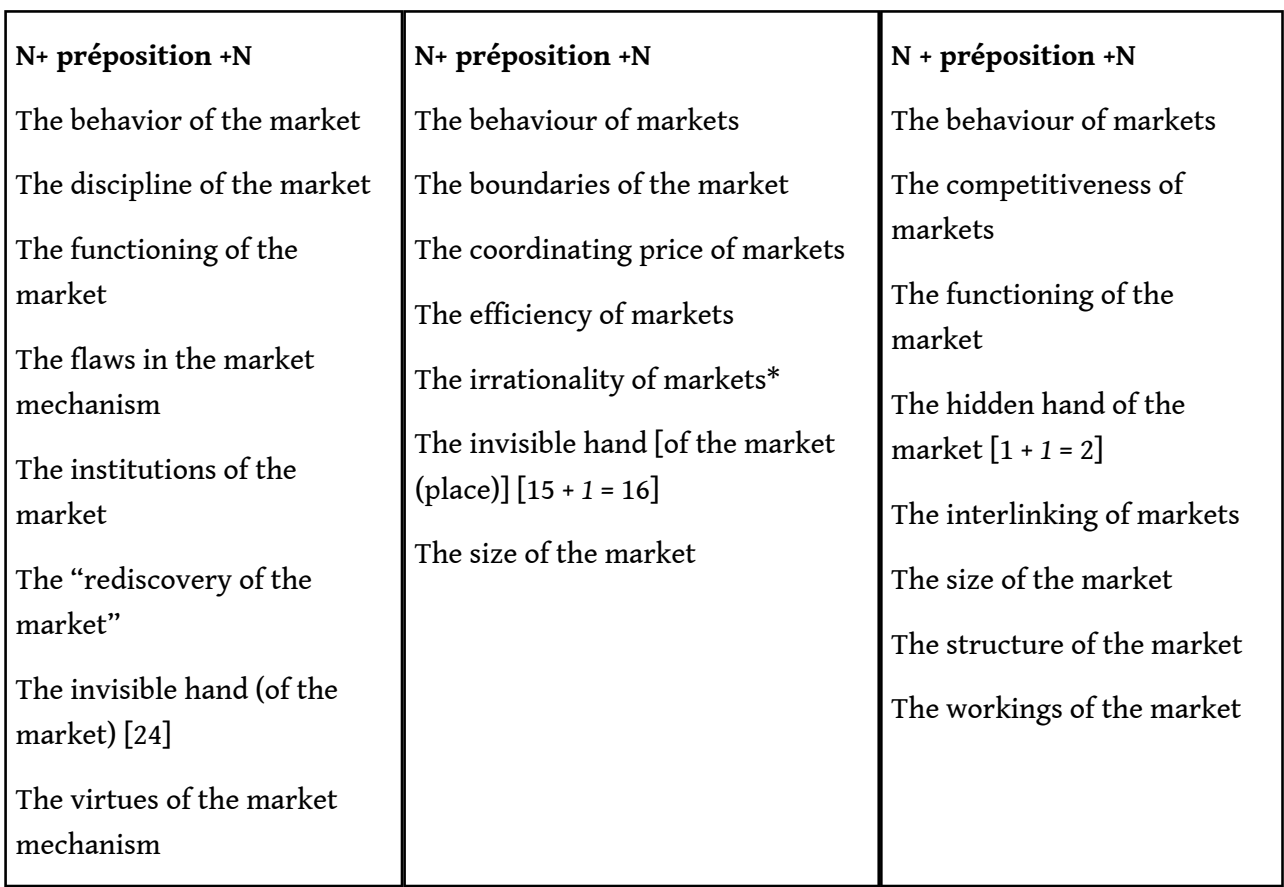

Le signe* indique une entrée dans l'index.

Le signe ${ }^{\circ}$ correspond à une entrée dans le glossaire.

Les chiffres / nombres en caractères droits font références à la partie microéconomie.

Les chiffres/nombres en italiques, font référence à la partie macroéconomie.

Tableau 2. Listes des verbes qui accompagnent le terme marché dans le texte des manuels

\begin{tabular}{|c|c|c|}
\hline $\begin{array}{c}\text { SAMUELSON \& } \\
\text { NORDHAUS }\end{array}$ & MANKIW & LIPSEY \& CHRYSTAL \\
\hline $\begin{array}{l}\text { Verbes } \\
\text { - Accomplish (59) } \\
\text { - Allocate }(27,59) \\
\text { - Balance forces (27) } \\
\text { - Clear } \\
\text { - Coordinate (26) } \\
\text { - Determine equilibrium, } \\
\text { prices and quantities (59) } \\
\text { general equilibrium (27) } \\
\text { incomes (225) } \\
\text { prices ( } 26,604) \\
\text { wages and outputs (26) } \\
\text { rates.. (27) } \\
\text { value ( } 615) \\
\text { - Deal out profits and } \\
\text { losses (28) } \\
\text { - Direct (25) } \\
\text { - Find the equilibrium } \\
\text { price (27) } \\
\text { - Function well (26) } \\
\text { - Match sellers and buyers } \\
\text { (27) } \\
\text { - Operate (255) } \\
\text { - Produce equilibrium (54) } \\
\text { - Solve problems (26, 27, } \\
321) \\
\text { - Work (26, 585) } \\
\text { - Work miracles (41) } \\
\text { - Work wonders (239) }\end{array}$ & $\begin{array}{l}\text { Verbes } \\
\text { - Allocate }(137,149,163, \\
203, \\
205,209,213,429) \\
\text { - Behave }(583) \\
\text { - Coordinate }(9,545,571) \\
\text { - Do things well }(203) \\
\text { - Guide (9) } \\
\text { - Interact (9) } \\
\text { - Maximize }(217) \\
\text { - Organize }(9,150,494) \\
\text { - Produce }(149) \\
\text { - Respond }(304,482) \\
\text { - Reward }(11) \\
\text { - Work }(10,63,84,154, \\
\text { 176, 224) }\end{array}$ & $\begin{array}{l}\text { Verbes } \\
\text { - Allocate }(184,279) \\
\text { - Behave }(46) \\
\text { - Clear }(534,535) \\
\text { - Decentralize power (286) } \\
\text { - Determine resource allocation (11)/ } \\
\text { price (144)/distribution of income } \\
\text { (286) } \\
\text { - Establish prices (286) } \\
\text { - Functions well (328) } \\
\text { - Generate technological changes (286) } \\
\text { efficient allocation of resources (310) } \\
\text { - Judges correctly (209) } \\
\text { - Produces results (215) } \\
\text { - Provide incentives (280) } \\
\text { - Punishes failures (215) } \\
\text { - Reacts to disturbances (200) } \\
\text { - Rewards success (215) } \\
\text { - Sorts out good decisions from bad ones } \\
\text { (215) } \\
\text { - Work (7, 32, 117, 280, 286, } 290,299 \text {, } \\
307,310,311)\end{array}$ \\
\hline
\end{tabular}




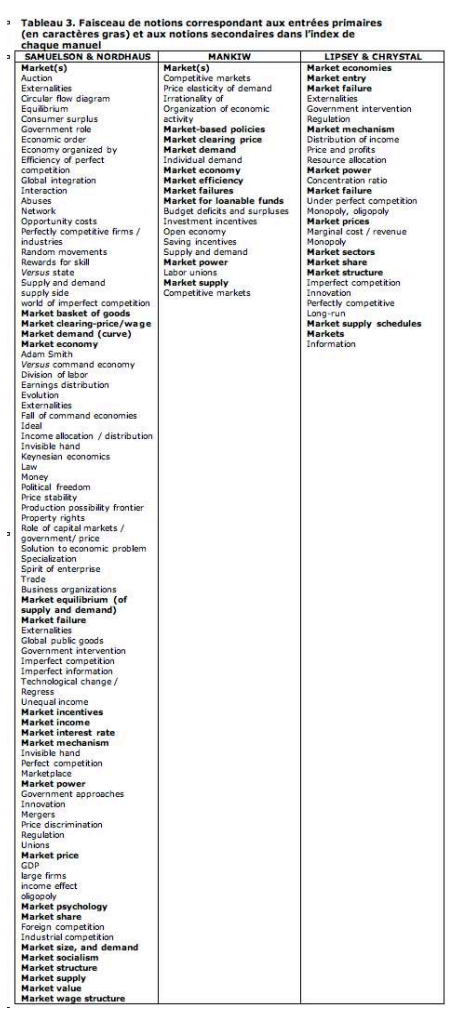

\section{NOTES}

1. Les italiques sont de notre fait.

2. Voir, à ce sujet, l'article de Resche (2005).

3. Les italiques sont de notre fait.

4. On peut consulter la revue en ligne Post-Autistic Economics Review <http://www.paecon.net>.

\section{RÉSUMÉS}

Cette étude constitue le premier volet d'une étude plus large sur le discours des manuels d'introduction aux grands principes de l'économie sur une ou plusieurs générations d'étudiants. On étudiera la notion centrale de "marché » à travers la présentation qui en est faite dans trois manuels largement diffusés et utilisés dans les universités anglo-saxonnes. On s'attachera à examiner tout ce qui contribue à en délimiter le sens et on tentera d'affiner l'approche de la définition en s'intéressant aussi bien à l'axe syntagmatique qu'à l'axe paradigmatique. La prise en compte d'un discours définitoire plus large s'avère utile pour cerner la vision de l'économie de marché qui est actuellement enseignée et véhiculée. Les résultats seront analysés en fonction des critiques exprimées par les défenseurs de l'approche « post-autiste ».

This paper is the first step towards a broader analysis of the discourse of economics textbooks. It focuses on the presentation of the market by the authors of three major, widely read textbooks 
on Anglo-Saxon university campuses. The notion is examined from various angles taking into account the syntagmatic and paradigmatic axes. It is shown that an extended approach to the notion of definition is required to understand how omnipresent the market is in the discourse of textbooks, whether explicitly or implicitly, through a network of equivalent or connected notions. The results are discussed against the background of the criticism expressed by the proponents of the post-autistic approach.

\section{INDEX}

Mots-clés : axes syntagmatique et paradigmatique, définition, manuel d'économie, marché, orthodoxie et hétérodoxie

Keywords : definition, economics textbook, market, orthodoxy and heterodoxy, paradigmatic and syntagmatic axes

\section{AUTEUR}

\section{CATHERINE RESCHE}

Catherine Resche est Professeur des universités en anglais économique à l'Université PanthéonAssas Paris 2. Ses travaux de recherche portent sur les différents aspects de l'anglais de spécialité dans le domaine économique : terminologie et phraséologie, néologie et métaphore, histoire de la pensée, genre et discours. Elle est membre de l'EA 2025 (Bordeaux 2) et du Cerlac (Paris 1 Panthéon-Sorbonne). Elle est responsable du groupe de travail « économie/gestion » au sein du GERAS et Secrétaire générale de la SAES. catherineresche@club-internet.fr 